\title{
熱帯低気圧による全球の高潮と沿岸脆弱性の推定 \\ Global Storm Surges by Tropical Cyclones and Vulnerability Projection in Coastal Zones
}

\author{
信岡尚道 $^{1}$ ・ 三村信男 ${ }^{2}$
}

\author{
Hisamichi NOBUOKA and Nobuo MIMURA
}

\begin{abstract}
This paper describes the vulnerability of coastal zones in the world taking account of storm surges, sea-level rise by global warming and population growth. Storm surges due to tropical cyclones since the year of 1951 were hindcasted by a numerical simulation in the world. The global map of the storm surges of which return period is 100 years was made in the resolution of 120 arc-seconds. The sea-level rise and population growth according to SRES scenario of IPCC was used to project the quantitative vulnerability of coastal zone by storm surges in the 21 st century. The projected results showed that the increase in the affected populations in the century will depend on the population growth in the world, especially Asia. Impact on sea-level rise with storm surges will also become clear after the year of 2050 .
\end{abstract}

\section{1. 序論}

21 世紀中には，地球温暖化に伴う海面上昇や人口増加 の圧力が沿岸域に加わり, 沿岸の脆弱性が増加すること は避けられない。無論, 海面上昇や人口成長率の程度は 国際社会の対応で変わるが，沿岸域管理の観点で 100 年 先は余裕のある時間とは言えない。そこで，シナリオべ ースで起こりうる事態を推定し, 事態に対抗する方策を 検討し始めることは重要である。海面上昇や人口増加は 世界規模のものであるので，それらの影響を個々の国や 地域で詳細に把握するとともに, 国際協調や貢献のため に全球で検討することも求められている。これまで全球 における沿岸域の脆弱性評価は, Hoozemansら（1993） の研究に始まり，Nichollsら（1999）の研究で精度が向 上するなど進められている。しかし，これらの研究では 潮汐と熱帯性低気圧による高潮の広域分布を簡易的に推 定しているに過ぎなかった，以上より，熱帯性低気圧に よる高潮の適切な算定に基づいて世界の沿岸域の脆弱性 を推定し，高潮の災害と防災に関する日本の豊富な知見 と技術を用いて，途上国を中心とした世界の高潮防災に 貢献していくことが求められるであろう.

本研究では，過去の熱帯低気圧による高潮を追算する ことから世界の高潮分布を明らかにして，21世紀中の海 面上昇と人口成長を考慮して, 沿岸の高潮浸水被害の増 加を推定するまでを目的とした。

\section{2. 高潮脆弱性の算定方法}

\section{(1) 高潮偏差の数値計算}

全球の既往高潮を算定するために，1951年～2007年ま

1 正会員 博 (工) 茨城大学准教授工学部都市システム工学科

2 正会員 工博 茨城大学教授広域水圈環境科学教育研究七 ンター
での熱帯低気圧のベストトラックとして，北大西洋につ いては日本の気象庁のものを, その他の領域である南太 平洋, 東太平洋, 大西洋, 北インド洋, 南インド洋につ いてはNOAAのWorld Data Center for Meteorology Ashevilleがデータベース化しているIBTrACSを用いた。

これらのデータの中で特に年代の古いものには中心気 圧が欠落しているものも少なくない. 欠落している中心 気圧の一部は次のように補間した。まず，領域ごとに中 心気圧值と最大風速值が同時刻に存在するデータで2次 曲線回帰式を求めた。次に中心気圧はないが風速值があ る場合で，同一熱帯低気圧内の別の同一時刻に中心気圧 と風速值が存在する場合, 風速の変化に対応する気圧の 変化量を回帰式から求め, 存在する中心気圧にその変化 量を加えることで補った。同一熱帯低気圧内に中心気圧 が全く存在していないが風速值が存在する場合には，回 帰式から直接に中心気圧を求めた。風速值が全くなく一 部に中心気圧がある場合には，中心気圧の欠落が 24 時間 以内の場合のみ線形補間で補った。

海岸線までの高潮はコリオリ力を考慮した球面座標の 線形浅水方程式を差分法で解き求めた. 空間格子間隔と 時間積分間隔は, 計算コストの制限から 120 秒角と 5 分 に設定し，領域ごとに計算を実行した。計算に用いた海 底地形データは，IHO \& IOCのGEBCO_08をもとに，可 能な限り内海が湖にならないように，また空間格子の粗 さによる浅海域の高潮低下を防ぐ狙いで，120秒角内に ある最浅デー夕を代表水深とした。この方法で作成され た地形では陸上の $0 \mathrm{~m}$ 地帯も海域となるため, USGSの GTOPO30で陸であるところは，陸と再設定した．各空 間格子上の海面気圧と風速分布はMyersの式を, その中 で必要な台風半径には加藤（2005）の式を用いた.

\section{（2） 100 年確率高潮偏差の計算}

高潮の危険性の基準を一致させるため，また 21 世紀末 
までには既往最高の高潮を上回る高潮が来襲することも 考えられるので, 高潮追算值を用いて極值統計解析によ り 100 年確率の高潮偏差を全球の沿岸で求めた. 解析に は, 合田（1990）の最小二乗法に基づく手法を用いた。 極值分布関数候補に極值 I 型分布，極值 II 型分布 (4種 類の形状母数) とWeibull分布 (4種類の形状母数) を採 用し, 最適な確率分布の判定には相関係数を用いた. 対 象時空間は高潮偏差の数值計算と同じであり年最大高潮 を用いたが，高潮追算值が粗で分布関数が全て棄却され た地点では全期間の最大高潮偏差を極值に代用した。

\section{（3）脆弱性評価システム}

高潮浸水による沿岸域の浸水面積と浸水人口を, 南北 180 度, 東西 360 度の全球で 60 秒角格子に区切り計算を 行う. 計算方法の詳細は信岡ら (2009) の方法と同一であ るので, ここでは概要と海水位の設定方法のみを記す.

\section{a) 沿岸高潮と浸水計算}

陸上地形にはGTOPO30を基本とし, 標高值がない部 分にはNASAのSRTM30で置き換え，60秒角格子に変換 したものを用いた。 60 秒角格子で表現された海岸線に, 120 分角格子で算定された高潮偏差の空間的に最も近い 值をあてはめた。高潮位には高潮偏差に満潮位を加えた 值としている。この満潮位については, イギリスの Hydro-graphic Office（2001）の tide table と海上保安庁の潮位 表に記されている值を優先したが，これらは極一部の海 岸線にしかないので大半の地点ではMatsumotoら（2000） の海洋潮汐モデルNAO.99bで算出した年間最高潮位（天 文潮）を用いた。

浸水については海岸線に沿った高潮位からレベル堪水 法を用いて 60 秒角格子上の浸水域を算出した. なお, こ こでは人工的な海岸防御施設を考慮していないので, 求 められる氾濫域は「潜在的高潮浸水域」となる.

\section{b) 温暖化のシナリオ}

将来の温暖化の程度には温室効果ガスの排出量により 変化する. また, 将来人口も社会状態により変化する. IPCCでは，これらのシナリオ（SRES Report）を作成し て, シナリオに従った検討を進めている. 海面上昇も SRES シナリオに基づいた気候モデルの結果から, 気温 上昇を元に海水の熱膨張を計算し, さらに氷河の融解な ど他の要因を加えて求められている. 本研究で用いたシ ナリオは, 代表的な $\mathrm{A} 1 \mathrm{~B}, \mathrm{~A} 2, \mathrm{~B} 1$ シナリオの3つである. $\mathrm{A} 1 \mathrm{~B}$ シナリオは 21 世紀半ばまで高度経済成長と人口増加 が続いたあと, 新技術が導入され温暖化がやや抑制され, 人口も減少するもの. A2 シナリオは地域の独自性が維持 され温暖化は進行し, 出生率の低下が緩やかなため人口 増加も続くもの. B1 シナリオでは, 省資源技術の導入, 持続可能性のための対策に重点が置かれ, 温暖化は抑制 され人口変動は $\mathrm{A} 1 \mathrm{~B}$ と同傾向となる.

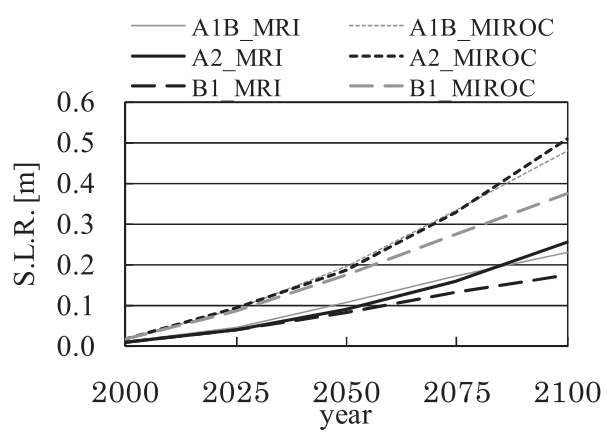

図-1 海面上昇シナリオ（元データはYukimotoら, 2001 および Hasumi ら, 2004)

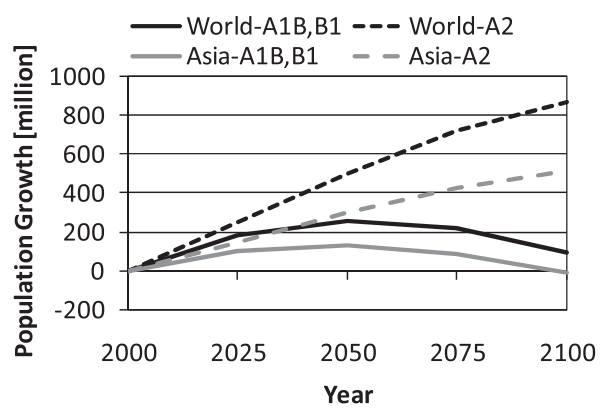

図-2 人口シナリオ（元データはCIESIN）

熱膨張による海面上昇の時系列には公開されているう ちのMRI-CGCM2.3.2a (Yukimoto ら, 2001) と MIROC3.2 (Hasumiら, 2004）による結果を用い, IPCC-AR4に記載 されている海面上昇值と比較して他の要因分を補正した 海面上昇量を本研究で用いた（図-1).人口分布にはCIESINのGPW3（UN）を用いて簡易配分により60秒角格子 ヘダウンスケーリングしたものを用いた，人口成長率シ ナリオには, SRES シナリオによる地域人口変化から各 国人口にダウンスケーリングしたCIESINの值を用いた (図-2).

\section{3. 全球の高潮分布}

\section{（1）高潮の計算精度検証}

高潮の数值シミュレーションでは, 全球の計算を行う がゆえ時空間解像度とも低下させており，また地形デー 夕も2章で述べたようにやや特殊なものを用いたので, 高潮偏差の精度を確認する. 図-3 は気象庁の記録ほか, 和達（1970）や宮崎（2003）がまとめている56地点の記 録（複数の記録がある場合にはその平均值）と計算值を 比較した結果である. 大きく異なる地点は, 高知や室戸 岬など外洋に面している海岸でWave Set-upを考慮でき ていないため, また湾や湖の中で計算に用いた海岸地形 が十分に再現されていなかった海岸であった. しかし多 くの地点で十分な精度の值が得られていると言え, 図の 
最右上 2 点の伊勢湾台風による名古屋, 第二室戸台風に よる大阪での高潮もかなり再現できている.

潮位についても, 観測データから求められたさく望平 均満潮位と 2 章で方法を説明したNAO.99bの観測地点で の年間最高潮位との比較をおこなった（図-4)。結果をみ ると平均して計算結果の方が 1 割高いが，この理由は用 いた潮位の種が異なるためと考えられる，以上を勘案す れば，潮位の計算值も，一部の再現性が悪いところもあ るが，全般的には良く表せていると言える。

\section{(2) 100 年確率の高潮分布}

高潮数值計算結果から極值統計解析をした 100 年確率 の全球の高潮分布を図-5に示す．図中の記号は，紙面の 都合上, 約 2 度角区画内の最高高潮偏差を抽出した結果 である. 高潮偏差の分布は, これまで知られている高潮 スポットと一致していると考えられる. 高潮偏差が $4 \mathrm{~m}$ を超えた地点は, ミシシッピー河口周辺, ガンジス・ブ ラマプトラ河口周辺およびハンチョウ湾周辺のみであっ

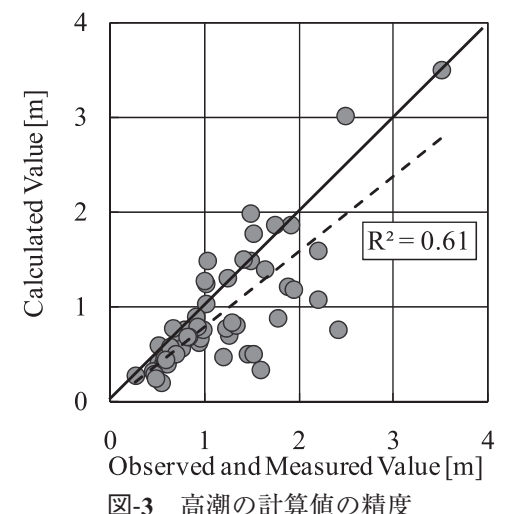

図-3 高潮の計算値の精度
た．地域別の偏差が大きい地点をみると，北西太平洋で は，フィリピン， ベトナム北岸，中国の南岸と日本，南 太平洋ではオーストラリア北西部と一部の島々, 北大西 洋ではメキシコ湾岸, 北インド洋ではバングラデシュ, ミャンマーやパキスタンのデルタ地带, 南インド洋では マダガスカル周辺と言える.

\section{4. 全球沿岸の脆弱性評価}

海面上昇が本研究内で最悪の $51 \mathrm{~cm}$ 上昇する 2100 年の A2 シナリオの最悪の場合に, 推定された潜在的な高潮浸 水域を図-6に黒塗で示している. 最悪のシナリオに関わ らず，全球の陸地面積から見ればごく限られた場所が影 響することが読み取れる。その中で浸水域が広い地点は, ミシシッピデルタ, ガンジス・ブラマプトラデルタ，イ ラワジデルタ, インダスデルタや長江デルタに加え, メ コンデルタなど, 大規模なデルタ地带である. また, ス マトラ島北東部やボルネオ島, アマゾンデルタやライン

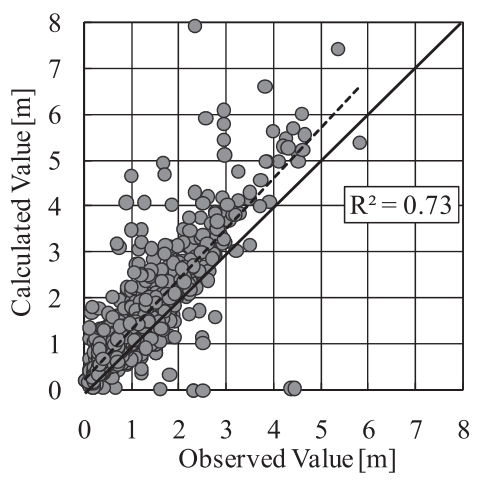

図-4 潮位の計算值の精度

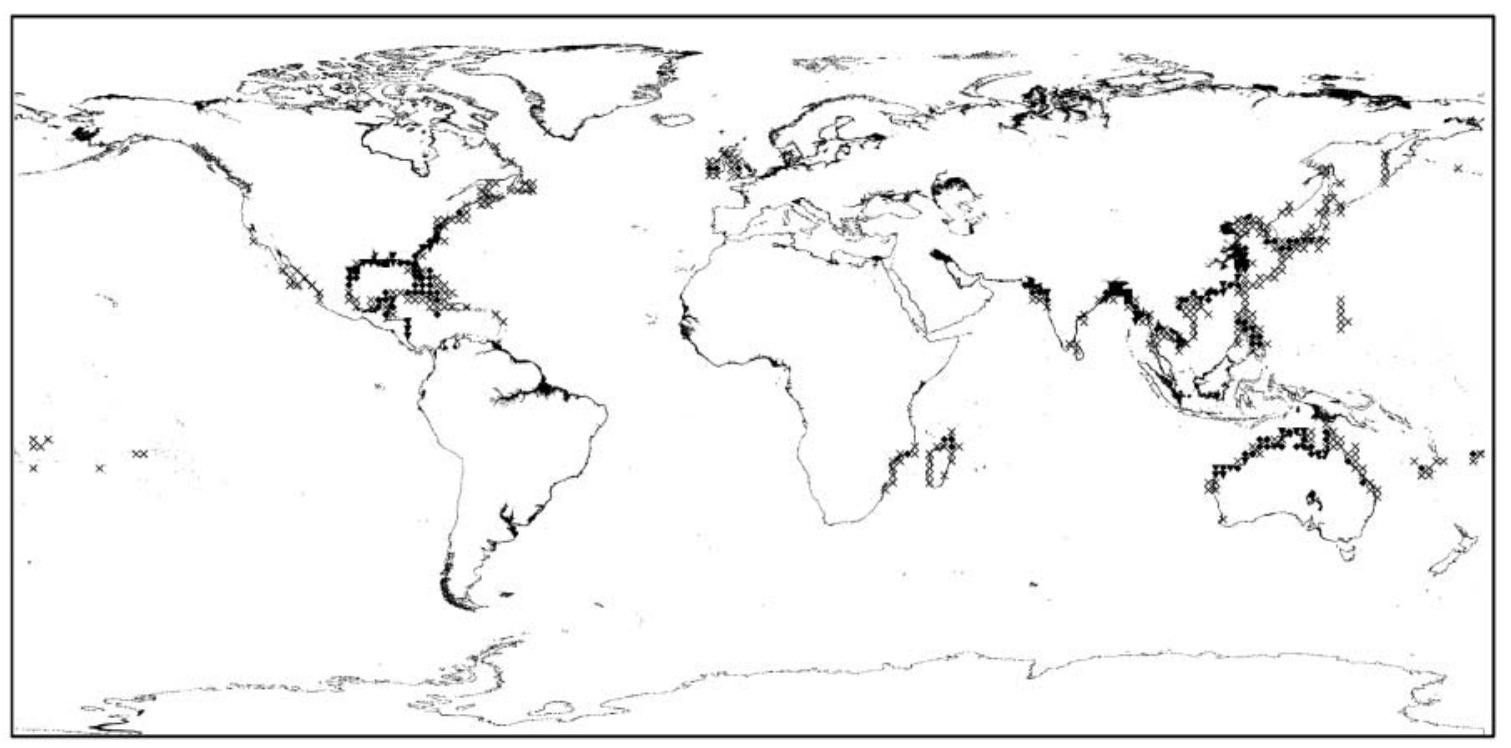

図-5 熱帯低気圧による100 年確率の高潮偏差の全球地図

:4m以上, $\boldsymbol{\nabla}: 3 \sim 4 \mathrm{~m}, \diamond: 2 \sim 3 \mathrm{~m}, \times: 1 \sim 2 \mathrm{~m}$, 解像度は約 2 度角に低下させている) 


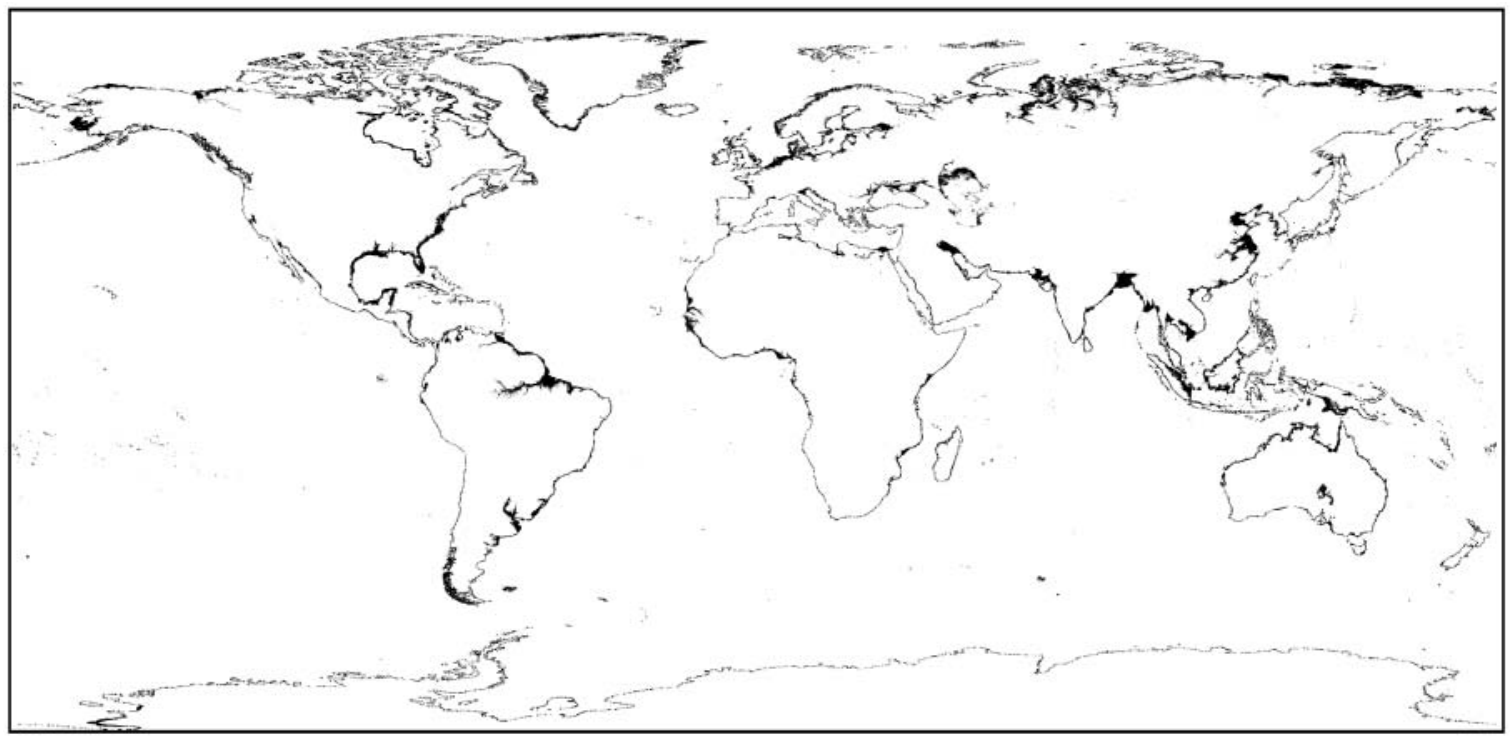

図-6 海面上昇 $51 \mathrm{~cm}$ 時の 100 年確率の高潮偏差による潜在的高潮汇濫域の全球地図

デルタなど熱帯低気圧の経路とならない場所でも，海面 上昇の影響により浸水域の拡がりがみられる。

推定された全球とアジアの 100 年確率による潜在的浸 水面積の拡大を A 2 シナリオの場合を例に図-7に示す. 図 の曲線が平均值で気候モデルによる海面上昇の差に伴う 不確実性の幅も各年で示している．海面の上昇（図-1） にしたがって浸水域も拡大していくこと, 最悪の場合に は現在に比べて高潮による浸水域の拡大が全球で 25 万 $\mathrm{km}^{2}$ になることが推定された。この浸水において全球の 中でアジアが占める割合は4分の1程度である.

次に潜在的浸水域に居住する人口の増加を推定した結 果を図-8に示す。この図ではSRES シナリオのうち B1 シ ナリオとほほ同じ人口成長をとる A1B シナリオと, A2 シナリオを比較している. 推定された結果はシナリオに より大きく異なる. A 2 シナリオでは最悪で世界で 6 億人 もの人口が新たに潜在的浸水の危険性を受けることにな り，その中でアジアが大半を占める結果となった. 他方, A1B シナリオでは，アジアの2050年をピークに，それ以 前の正の人口成長とその以後の負の人口成長に伴い，浸 水人口も増減する。 オセアニアの浸水人口の増加は世界 の同人口と比べ非常に少ないこともわかる. また，気候 モデルの結果による不確実性の幅も各年で示しているが, 浸水面積のそれと比べると狭い. 海面上昇や浸水域拡大 に比べ浸水人口の増加が早いこともみてとれる.

\section{5. 浸水人口増加の考察}

総人口の少ない地域でも浸水人口増加が占める割合が 大きければ，地域における適応に要する相対的負担は大 きい. 図-9は世界と 2 地域の浸水人口増加が総人口占める

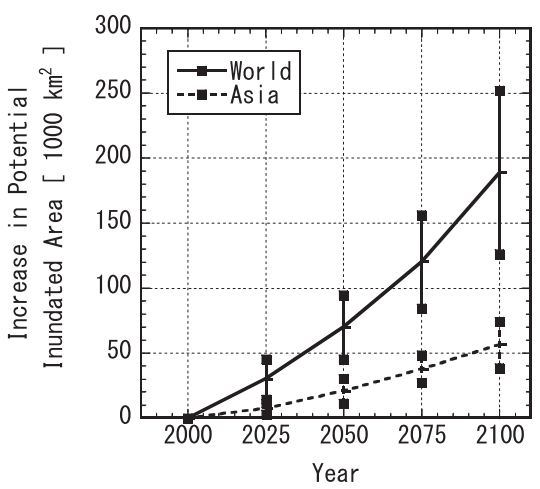

図-7 100年確率による潜在的高潮浸水域増加と不確実性

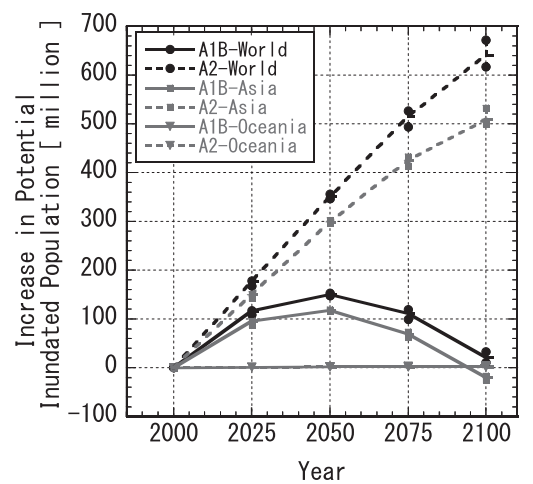

図-8 100 年確率による潜在的高潮浸水域増加と不確実性

割合の推移であり, 浸水人口増加の要因として本結果に 考慮できている人口成長 (Population Growth) と海面上昇 (S.L.R.) が占める割合も同時に示している.オセアニア での総割合は，アジアの割合と同程度かより大きいこと がわかる.アジアでは浸水人口増加に人口成長が大きく 

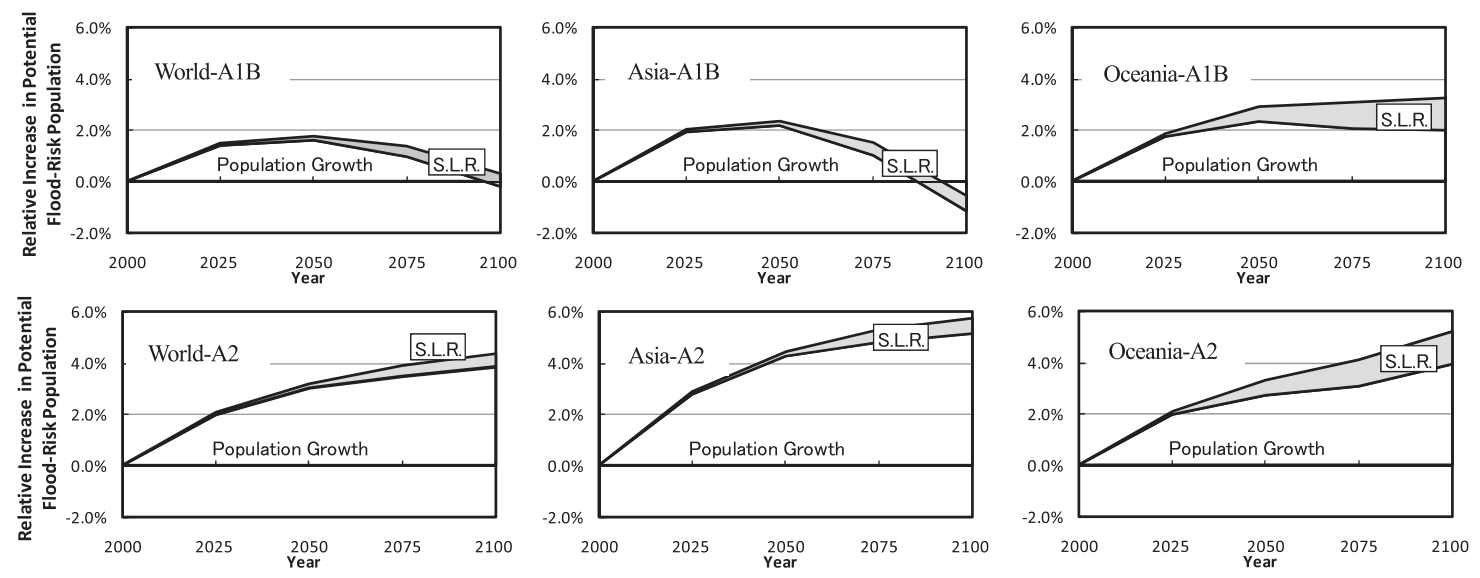

図-9 100 年確率の高潮による相対的浸水人口増加と要因

関係しており，全球でも同様の傾向を導かれることが両 シナリオの結果からわかる，海面上昇の影響割合は 21 世 紀後半に, 特にオ七アニアで顕著になることもみてとれ る.なお, 人口成長の大きな国は途上国であり, 現在で は十分な海岸防御施設を保持できていない国である.

\section{6. 結論}

熱帯低気圧にともなう全球の高潮偏差の 100 年確率值 を数值計算による50年間以上の追算と極值統計解析によ り求めた。作成した全球の高潮偏差図は，これまでの高 潮災害から得てきた知識と矛盾することはなく，今後の 高潮防災の国際貢献策として活用できるものと言える. 21 世紀中の潜在的高潮浸水域と浸水域の居住人口を全球 で定量的に推定した．沿岸域は狭い範囲にあるため海面 が $50 \mathrm{~cm}$ 程度上昇の場合の高潮浸水結果でも, 相当に大 きな寸法の地図でないと, 大規模なデル夕などの低平地 を除いて, 表示するのが難しい. しかし, 狭い沿岸域で も浸水域は拡大するので, そこの居住人口は沿岸域管理 政策上, 重要であると言えた。潜在的浸水人口の増加は 浸水域の拡大よりも早く，最悪の場合，2100年までには 6 億人増えると推定された. 世界の中でアジアの浸水人 口の増加が相当に大きい. 世界の浸水人口の増加に占め る要因には, 21 世紀前半は正の人口成長の影響が大きく, 後半にはオセアニアを始めとして海面上昇による影響も 顕著になる。しかし， A1BシナリオやB1シナリオにお いては同後半に，アジアを中心とした負の人口成長によ り，浸水人口も減少することを定量的に示した.

以上より, 高潮の被害拡大が推定された地域を中心に, 気候変化と人口変動を勘考した防災政策, 長期沿岸域管 理計画が重要になると言える.

謝辞: 本研究は環境省「地球環境研究総合推進費 (S-04:温 暖化の危険な水準及び温室効果ガス安定化レベル検討の
ための温暖化影響評価に関する研究)，代表：三村信男 (茨城大学)」と, 文部科学省 $「 21$ 世紀気候変動予測革新 プログラム，プログラム統括：松野太郎，西岡秀三」に よる研究成果の一部である。高潮の計算精度分析には大 澤里津氏（当時, 茨城大学大学院生）の協力を得た. こ こに感謝の意を表する。

\section{参 考 文 献}

加藤史訓（2005）：高潮危険度評価に関する研究, 国土技術 政策総合研究所資料, No.275, 108p.

合田良實（1990）：港湾構造物の耐波設計－波浪工学への序 説一, 鹿島出版会, 333p.

信岡尚道・三村信男・田村 誠（2009）：21世紀におけるア ジア・オセアニア沿岸の基礎的脆弱性の推定, 地球環境 研究論文集, 17, pp. 123-132.

宮崎正衛（2003）：高潮の研究〜その実例とメカニズム, 成 山堂書店, $134 \mathrm{p}$.

和達清夫（1970）：津波・高潮 - 海洋災害, 共立出版社, 377p.

Center for International Earth Science Information Network (CIESIN): Country-level Population and Downscaled Projections based on the B2 Scenario, 1990-2100, 2002. [digital version]. Palisades, NY: CIESIN, Columbia University. Available at http://www.ciesin. columbia.edu/datasets/downscaled (2009.1 参照).

Hasumi H., and E. Emori (2004) : K-1 Coupled GCM (MIROC) Description, K-1 Technical Report, CCSR/NIES/ FRCGC, 34p.

Hoozemans, F.M.J., M. Marchand and H.A. Pennekamp (1993) : A Global Vulnerability Assessment, Sea-Level Rise, Second Revised Edition, Delft Hydraulics, 184p.

Hydrographic Office (2001) : Admiralty Tide table, The Hydrographer of the Navy, United Kingdom, Vol.1 and Vol.2, 440p and 474P.

Matsumoto, K., T. Takanezawa, and M. Ooe (2000) : Ocean Tide Models Developed by Assimilating TOPEX/POSEIDON Altimeter Data into Hydrodynamical Model: A Global Model and a Regional Model Around Japan, Journal of Oceanography, 56, pp.567-581.

Nicholls, R. J., M.J.F. Hoozemans and M. Marchand (1999) : Increasing flood risk and wetland losses due tu global sea-level rise: regional and global analyses, Global Environmental Change, 9, SS69- S87.

Yukimoto, S. and A. Noda (2001) : Improvements of the Meteorological Research Institute Global Ocean-Atmosphere Coupled GCM (MRICGCM2) and Its Climate Sensitivity, CGER's Supercomputer Activity Reports, Vol.10, CGER-1054-2002, CGER/NIES, pp3744, 2001. 